\title{
Leaching of copper and nickel in soil-water systems contaminated by bauxite residue (red mud) from Ajka, Hungary: the importance of soil organic matter
}

\author{
Cindy L. Lockwood • Douglas I. Stewart • Robert J. G. Mortimer • \\ William M. Mayes • Adam P. Jarvis • Katalin Gruiz • Ian T. Burke
}

Received: 12 December 2014 / Accepted: 24 February 2015 / Published online: 12 March 2015

(C) The Author(s) 2015. This article is published with open access at Springerlink.com

\begin{abstract}
Red mud is a highly alkaline $(\mathrm{pH}>12)$ waste product from bauxite ore processing. The red mud spill at Ajka, Hungary, in 2010 released 1 million $\mathrm{m}^{3}$ of caustic red mud into the surrounding area with devastating results. Aerobic and anaerobic batch experiments and solid phase extraction techniques were used to assess the impact of red mud addition on the mobility of $\mathrm{Cu}$ and $\mathrm{Ni}$ in soils from near the Ajka spill site. Red mud addition increases aqueous dissolved organic carbon (DOC) concentrations due to soil alkalisation, and this led to increased mobility of $\mathrm{Cu}$
\end{abstract}

Responsible editor: Philippe Garrigues

Prepared for Environmental Science and Pollution Research, 02 March 2015.

Electronic supplementary material The online version of this article (doi:10.1007/s11356-015-4282-4) contains supplementary material, which is available to authorized users.

C. L. Lockwood · R. J. G. Mortimer · I. T. Burke $(\bowtie)$

School of Earth and Environment, University of Leeds, Leeds LS2

9JT, UK

e-mail: I.T.Burke@leeds.ac.uk

D. I. Stewart

School of Civil Engineering, University of Leeds, Leeds LS2 9JT, UK

W. M. Mayes

Centre for Environmental and Marine Sciences, University of Hull, Scarborough YO11 3AZ, UK

\section{A. P. Jarvis}

School of Civil Engineering and Geosciences, Devonshire Building, Newcastle University, Newcastle Upon Tyne NE1 7RU, UK

\section{A. P. Jarvis}

Department of Applied Biotechnology and Food Science, Budapest University of Technology and Economics, St Gellért sq. 4,

1111 Budapest, Hungary and Ni complexed to organic matter. With Ajka soils, more $\mathrm{Cu}$ was mobilised by contact with red mud than $\mathrm{Ni}$, despite a higher overall Ni concentration in the solid phase. This is most probably because $\mathrm{Cu}$ has a higher affinity to form complexes with organic matter than $\mathrm{Ni}$. In aerobic experiments, contact with the atmosphere reduced soil $\mathrm{pH}$ via carbonation reactions, and this reduced organic matter dissolution and thereby lowered $\mathrm{Cu} / \mathrm{Ni}$ mobility. These data show that the mixing of red mud into organic rich soils is an area of concern, as there is a potential to mobilise $\mathrm{Cu}$
K. Gruiz

Centre for Applied Geoscience, Eberhard-Karls-University

Tübingen, 72076 Tübingen, Germany

Present Address:

C. L. Lockwood

Centre for Applied Geoscience, Eberhard-Karls-University

Tübingen, 72076 Tübingen, Germany

Present Address:

R. J. G. Mortimer

School of Animal, Rural and Environmental Sciences, Nottingham

Trent University, Brackenhurst Campus,

Southwell, Nottinghamshire NG25 0QF, UK 
and $\mathrm{Ni}$ as organically bound complexes, via soil alkalisation. This could be especially problematic in locations where anaerobic conditions can prevail, such as wetland areas contaminated by the spill.

Keywords Kolontár · Ajka · Red mud · Nickel · Copper . DOC $\cdot$ Soil organic matter $\cdot$ Solid phase extraction

\section{Introduction}

The accidental release of $\sim 1$ million $\mathrm{m}^{3}$ (Reeves et al. 2011; Adam et al. 2011) of bauxite processing residue (red mud) from the Ajkai Timfoldgyar Zrt alumina plant in Ajka, western Hungary, in October 2010 focused world attention on the public health and environmental hazards associated with red mud. The spill caused damage to property, serious injuries and killed 10 people (Enserink 2010; Adam et al. 2011). An estimated $40 \mathrm{~km}^{2}$ of low lying agricultural land and riparian wetlands were affected and the red mud was transported $120 \mathrm{~km}$ downstream by rivers, eventually reaching the Danube (Reeves et al. 2011; Mayes et al. 2011).

Red mud is the name given to the fine fraction residue produced during alumina extraction from bauxite by the Bayer process. The composition of red mud is dependent upon the bauxite ore used (Hind et al. 1999; Liu et al. 2007) but is typically comprised of iron oxides, quartz, sodium aluminosilicates, titanium dioxide, calcium carbonate/aluminate and sodium hydroxide (Hind et al. 1999; Grafe et al. 2011; Gelencser et al. 2011). Red mud also contains elevated concentrations of potentially toxic metal(loid)s including Al, As, $\mathrm{Cr}, \mathrm{Cu}, \mathrm{Ni}, \mathrm{Mo}, \mathrm{V}$ and $\mathrm{Zn}$. Although the majority of these problematic elements are found associated with sparingly soluble minerals (Mayes et al. 2011; Rubinos and Barral 2013), several oxyanion-forming elements (e.g. Al, As, Mo and V) have been found to be mobile in waters associated with the red mud (Lockwood et al. 2014; Lehoux et al. 2013; Burke et al. 2013; Milacic et al. 2012). The use of $\mathrm{NaOH}$ during the Bayer process means that red mud is very caustic unless the waste is neutralised prior to disposal (Grafe et al. 2011; Power et al. 2011). At Ajka, the red mud had a $\mathrm{pH}>12$ (Adam et al. 2011), making it a hazardous substance as defined by the Basel Convention (Secretariat of the Basel Convention 2011). It is also highly saline and sodic (e.g. Ajka leachate had conductivity of up to $160 \mathrm{mS} \mathrm{cm}{ }^{-2}$ ); therefore, Na stress to soils and plants has been noted as a consequence of the Ajka spill (Ruyters et al. 2011).

Several studies at Ajka have investigated the effects of red mud on human health (Gelencser et al. 2011), soil toxicity (Anton et al. 2012), freshwater and soil ecology (Klebercz et al. 2012; Rekasi et al. 2013), the mobility of red mud associated trace metals in the wider environment (Mayes et al.
2011; Burke et al. 2012; Lehoux et al. 2013), and the effects dosing of rivers and streams with acid and gypsum to reduce pH (Renforth et al. 2012; Burke et al. 2013). After the Ajka disaster, the affected land was treated in two different ways: (1) removal of the red mud where deposits were $>5 \mathrm{~cm}$ and (2) ploughing the red mud into land where deposits were $<5 \mathrm{~cm}$. The land clean-up began a few weeks after the disaster, but in some areas, the red mud covered the soils for several months (Rekasi et al. 2013), and remediation of wetland areas was not attempted.

Humic acids are an important component of soil organic matter (SOM) whose solubility varies with $\mathrm{pH}$. They are produced by microbial degradation of plant and animal residues and represent a range of chemically similar compounds that contain carboxyl and phenolate groups and behave functionally as a dibasic (occasionally tri-basic) acid (Stevenson 1994). As a result, the amount of dissolved organic matter (DOC) in soil pore water tends to increase as the $\mathrm{pH}$ increases (Cheshire et al. 1977; Yin et al. 2002). Indeed, addition of dilute $\mathrm{NaOH}$ is used as a standard method for extracting humic acids from soil (Parsons 1988; Sparks et al. 1998). Thus, the addition of red mud to soil, which increases the $\mathrm{pH}$, tends to increase the amount of DOC in soil pore waters (Lombi et al. 2002; Lehoux et al. 2013; Rekasi et al. 2013). However, the degree to which a particular soil is affected will depend on the nature of that soil. For example, sandy soils will undergo a greater $\mathrm{pH}$ increase, as they lack the intrinsic buffering capacity of a clay soil, and an organic-rich soil will release more DOC into soil pore waters upon soil alkalisation (Lehoux et al. 2013).

In the environment, copper and nickel most commonly occur as $\mathrm{M}^{2+}$ cations and are generally more mobile under acidic conditions as they tend to adsorb strongly to minerals at neutral and alkaline $\mathrm{pH}$. Nickel also can form insoluble hydroxides $\left(\right.$ as $\left.\mathrm{Ni}(\mathrm{OH})_{2}\right)$ as $\mathrm{pH}$ increases above $\mathrm{pH} 9$ (Richter and Theis 1980; Bradbury and Baeyens 2009). However, $\mathrm{Ni}$ (II) and particularly $\mathrm{Cu}$ (II) can form strong complexes with organic molecules (Ashworth and Alloway 2004; Baken et al. 2011), especially those that contain carboxyl moieties (Moon and Peacock 2013). High DOC in soil pore waters can therefore have a major impact on the aqueous concentrations of trace metals in circumneutral and alkaline pore waters (Davis 1984; Ashworth and Alloway 2004) despite the tendency of the metal cations to adsorb to minerals at neutral to high pH (Wu et al. 2001, 2002).

$\mathrm{Cu}$ is redox sensitive and can be reduced to $\mathrm{Cu}(\mathrm{I})$ or $\mathrm{Cu}(0)$ in reducing environments forming insoluble oxides, sulphides and elemental $\mathrm{Cu}$ (Fulda et al. 2013a; Weber et al. 2009) that can significantly reduce the overall environmental mobility of $\mathrm{Cu}$. The mobility of Ni is less affected by the changes in redox potential found in natural environments, but sorption of $\mathrm{Ni}$ to $\mathrm{Fe}$ and especially Mn oxides is very important in controlling aqueous Ni concentrations (Peacock and Sherman 2007). 
Therefore, in reducing environments (where $\mathrm{Mn}$ and $\mathrm{Fe}$ oxides tend to be dissolved during bioreduction), Ni mobility can be indirectly affected by changes in the availability of sorption sites.

In previous studies of red mud-soil mixtures, increased $\mathrm{Cu}$ mobility has been observed in both field trials (Lombi et al. 2002) and laboratory tests (Rekasi et al. 2013). Since the Ajka spill, increased concentrations of both $\mathrm{Cu}$ and $\mathrm{Ni}$ have been found in the Torna and Marcel Rivers (Nagy et al. 2013). However, if reducing conditions developed with time in water-logged soil, $\mathrm{Cu}$ may speciate as less soluble $\mathrm{Cu}(\mathrm{I})$ and $\mathrm{Cu}(0)$ phases at lower redox potentials, or the reductive dissolution of $\mathrm{Fe}$ and $\mathrm{Mn}$ oxides may reduce the availability of sorption sites and promote both $\mathrm{Cu}$ and $\mathrm{Ni}$ solubility. Thus, it is important to understand the potential effects of red mud addition to soils on $\mathrm{Cu}$ and $\mathrm{Ni}$ mobility under both aerobic and anaerobic conditions.

This paper reports results from long-term aerobic and anaerobic batch experiments that investigate the mobility of $\mathrm{Cu}$ and $\mathrm{Ni}$ in red mud-contaminated soil-water systems that are representative of soil conditions after the Ajka disaster remediation efforts. The specific objectives of this study were (1) to determine the potential for $\mathrm{Cu}$ and $\mathrm{Ni}$ release in red mud affected soil-water systems, (2) to determine the effect of complexation with soil derived DOC on metal behaviour as a function of soil type, and (3) to discuss the long-term implications of ploughing in red mud to soils as an emergency remediation method and the potential hazards associated with unremediated wetland areas.

\section{Materials and methods}

Field sampling and sample handling

Sampling was undertaken in May 2011 (see Fig. 1). Red mud (RM) was sampled from within Cell X of the Ajka impoundment (Location $47^{\circ} 05^{\prime} 18.48^{\prime \prime} \mathrm{N}, 17^{\circ} 29^{\prime} 46.77^{\prime \prime} \mathrm{E}$ ), and red mud leachate was collected from an open leachate pond at the same location. Three uncontaminated soils were sampled from locations in the Torna and upper Marcal river catchments unaffected by the release of red mud in 2010 (see Fig. 1 for sampling locations). Two were agricultural top soils (one was organic-rich (OR), the other a sandy soil (SS)) and the third was collected from $50 \mathrm{~cm}$ from below the surface (i.e. beneath the rootlet layer) of a wetland (WL). All samples were stored at $4{ }^{\circ} \mathrm{C}$ in polythene containers. The wetland soil was stored anaerobically using Anaerogen ${ }^{\mathrm{TM}}$ sachets.

Long-term batch experiments

Batch microcosm experiments were established under both aerobic and anaerobic conditions. Two different red mudsoil mixtures were prepared for each soil type, and triplicate microcosms were prepared for each condition. A $9 \%$ red mud addition (by dry weight) was chosen as an analogue for where red mud had been ploughed into fields (based on $\sim 5 \mathrm{~cm}$ ploughed to a typical depth of $40-50 \mathrm{~cm}$, an approximate 1:10 mixing ratio). The $33 \%$ addition was used as a worst case scenario for any unremediated wetlands. Deionised water was added in a 5:1 ratio to the amount of soil.

Anaerobic experiments were carried out in $120-\mathrm{mL}$ glass serum bottles, which were purged with nitrogen before capping and crimp sealing. Aerobic experiments were carried out in 50-mL polypropylene centrifuge tubes and opened every week day for an hour in order to exchange the experimental headspace with air and prevent anaerobic conditions forming due to microbial respiration. Both aerobic and anaerobic experiments were incubated in the dark at $21^{\circ} \mathrm{C}$ and sampled periodically over 100-120 days. During sampling, bottles/ tubes were shaken, and 2- to 4-mL aliquots of soil/RM slurry were extracted. Aseptic technique was used where appropriate. Extractions were centrifuged ( $3 \mathrm{~min}, 6000 \mathrm{~g}$ ), and the water $\mathrm{pH}$ and oxidation/reduction potential (ORP) were determined. The aqueous phase was filtered $(0.2 \mu \mathrm{m})$ and acidified with $2 \% \mathrm{HNO}_{3}$ for ICP-MS analysis. At the end point of each experiment between 6 and $15 \mathrm{~mL}$ of slurry that was extracted and centrifuged, the solutions were used for dissolved organic carbon (DOC) analysis and solid phase extraction (SPE) experiments. For each soil type, control experiments without red mud were incubated under anaerobic and aerobic conditions as described above.

Fig. 1 Map of the area affected by the red mud spill in October 2010, showing sampling locations indicated by filled circles, from May 2011 taken from Lockwood et al. (2014)

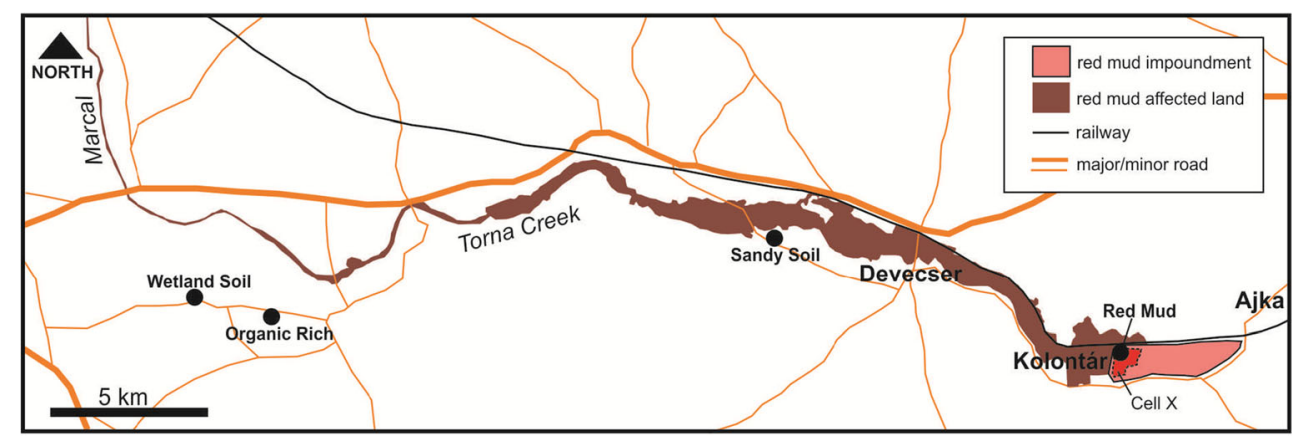


Geochemical methods

ORP (as an indicator for Eh) and $\mathrm{pH}$ were measured using a Thermo Scientific Orion Dualstar pH/ISE benchtop meter ( $\mathrm{pH}$ was calibrated daily at $\mathrm{pH}$ values of 4,7 and 10; a new factory calibrated ORP electrode was used). Aqueous $\mathrm{Cu}$ and $\mathrm{Ni}$ concentrations were determined using a PerkinElmer Elan DRCII ICP-MS. DOC in end point solutions was determined by a multi $\mathrm{N} / \mathrm{C}^{\circledR} 2100$ analyser using thermocatalytic oxidation, MC-NDIR detection analysis. Sequential extractions were performed on triplicate Ajka red mud samples (collected from location K1 in Mayes et al. (2011) in December 2010) following an optimised Tessier procedure (Rauret et al. 1989) that partitioned $\mathrm{Cu}$ and $\mathrm{Ni}$ into five operationally defined fractions. Extractant $\mathrm{pH}$ was checked after each extraction stage and to ensure it conformed to protocol, and $\mathrm{Cu}$ and $\mathrm{Ni}$ concentrations were determined on an Optima 5300 DV ICP-OES.

\section{SPE}

The end point solutions were passed through Isolute ${ }^{\mathrm{TM}} \mathrm{C} 18$ non-polar SPE filters $(1 \mathrm{~g} / 6 \mathrm{~mL})$ to retain organic substances (and thereby any organically bound metals). These filters were conditioned according to the manufacturer's instructions, and the solutions acidified to $\mathrm{pH} 5.5$ prior to filtration using $\mathrm{HNO}_{3}$ (the optimum $\mathrm{pH}$ for maximum organic matter retention by Isolute C18 filters (Thomas 2000)). The filtrates were further diluted with $2 \% \mathrm{HNO}_{3}$ for ICP-MS analysis to determine the inorganic/free aqueous metal concentrations. The concentration of organically bound metals was calculated from the difference in aqueous metals concentrations measured before (total $\left[\mathrm{M}^{+}\right]$) and after SPE (inorganic/free $\left[\mathrm{M}^{+}\right]$). It should be noted that this is an operationally defined extraction, and a small percentage of metals bound to organic compounds may not be retained by $\mathrm{C} 18$ filters and thus appear in the aqueous fraction. The percentages calculated from this method will therefore be used as an indicator for the amount of organically bound metals.

\section{Results}

Sample characterisation

The RM and the three different soil samples have been fully described previously (Lehoux et al. 2013) and are summarised in Table 1. X-ray fluorescence (XRF) analysis of the samples is presented in Table A (Online Resource). Briefly, the RM mineral content was dominated by hematite $\left(\mathrm{Fe}_{2} \mathrm{O}_{3}\right)$, calcite $\left(\mathrm{CaCO}_{3}\right)$, magnetite $\left(\mathrm{Fe}_{3} \mathrm{O}_{4}\right)$, cancrinite $\left(\mathrm{Na}_{6} \mathrm{CaAl}_{6} \mathrm{Si}_{6}\left(\mathrm{CO}_{3}\right) \mathrm{O}_{24} \cdot 2 \mathrm{H}_{2} \mathrm{O}\right)$ and hydrogarnet $\left(\mathrm{Ca}_{3} \mathrm{AlFe}\left(\mathrm{SiO}_{4}\right)\left(\mathrm{OH}_{8}\right)\right.$ with residual boehmite $(\gamma-\mathrm{AlOOH})$ and gibbsite $\left(\mathrm{Al}\left(\mathrm{OH}_{3}\right)\right)$ phases, which is very similar to other red mud from the breach area (Gelencser et al. 2011; Burke et al. 2012). The concentrations of $\mathrm{Cu}$ and $\mathrm{Ni}$ in red mud were 104 and $361 \mathrm{mg} \mathrm{kg}^{-1}$, respectively. In sequential extractions on the red mud (see Fig. 2 and Online Resource Table B), an extremely low proportion of the $\mathrm{Cu}$ and $\mathrm{Ni}$ was exchangeable with $\mathrm{Mg}^{2+}$. Most ( $\sim 80 \%$ ) of the $\mathrm{Cu}$ present was progressively leached from the red mud by a series of weakly acidic (pH 1.5-5) leaching solutions. The majority ( $75 \%$ ) of the $\mathrm{Ni}$, however, was only released from the red mud by total digestion.

All three soils had similar mineralogy, with quartz as the dominant mineral, and feldspars and clays also present. The principal differences between them were in the organic carbon contents, and the proportions of the $0.5 \mathrm{~N} \mathrm{HCl}$ extractable iron in the $\mathrm{Fe}$ (II) oxidation state (Table 1). Soil OR had the highest concentrations of $\mathrm{Cu}\left(12 \mathrm{mg} \mathrm{kg}^{-1}\right)$ and $\mathrm{Ni}\left(23 \mathrm{mg} \mathrm{kg}^{-1}\right)$. Soil WL had $6 \mathrm{Cu}$ and $14 \mathrm{mg} \mathrm{kg}^{-1} \mathrm{Ni}$. Soil SS had the lowest concentrations of $\mathrm{Cu}\left(2 \mathrm{mg} \mathrm{kg}^{-1}\right)$ and $\mathrm{Ni}\left(5 \mathrm{mg} \mathrm{kg}^{-1}\right)$. PCA analysis (Fig. A, Online Resource) shows that these soils were similar to other reference soils from the area that were unaffected by the 2010 RM spill (Mayes et al. 2011; Lehoux et al. 2013).

\section{Effect of RM addition on microcosm $\mathrm{pH}$ and DOC}

The $\mathrm{pH}$ of the soil-only control experiments was very similar under both anaerobic and aerobic conditions and was between

Table 1 Red mud and soil characterisation

\begin{tabular}{|c|c|c|c|c|c|c|c|c|}
\hline Soil sample & Soil type & $\begin{array}{l}\text { Total Cu} \\
\left(\mathrm{mg} \mathrm{kg}^{-1}\right)^{\mathrm{a}}\end{array}$ & $\begin{array}{l}\text { Total Ni } \\
\left(\mathrm{mg} \mathrm{kg}^{-1}\right)^{\mathrm{a}}\end{array}$ & $\mathrm{pH}$ & $\begin{array}{l}\% 0.5 \mathrm{M} \mathrm{HCl} \text { extractable } \\
\text { iron as } \mathrm{Fe}(\mathrm{II})\end{array}$ & Major minerals present & TOC $(\%)$ & $\begin{array}{l}\text { BET surface } \\
\text { area }\left(\mathrm{m}^{2} \mathrm{~g}^{-1}\right)\end{array}$ \\
\hline Red mud & $\mathrm{n} / \mathrm{a}$ & 104 & 361 & 12.3 & $22( \pm 3)$ & $\begin{array}{l}\text { Hematite, calcite, hydrogarnet, } \\
\text { boehmite, cancrinite }\end{array}$ & 0.23 & $14.40( \pm 0.07)$ \\
\hline Soil OR & Sandy clay loam & 12 & 23 & 7.0 & $9.6( \pm 2)$ & $\begin{array}{l}\text { Quartz, albite, clinochlore, } \\
\text { muscovite, ilite }\end{array}$ & 4.15 & $1.78( \pm 0.20)$ \\
\hline Soil WL & Sandy clay loam & 6 & 14 & 7.9 & $87.3( \pm 14)$ & $\begin{array}{l}\text { Quartz, albite, clinochlore, } \\
\text { muscovite, ilite }\end{array}$ & 1.14 & $2.61( \pm 0.01)$ \\
\hline Soil SS & Sandy loam & 2 & 5 & 7.9 & $4.6( \pm 2)$ & Quartz, albite, clinochlore, ilite & 0.74 & $0.94( \pm 0.01)$ \\
\hline
\end{tabular}

All data except for total $\mathrm{Cu}$ and total Ni was taken from Lehoux et al. (2013). Note that the samples' names used here differ to those in Lehoux et al. (2013), for clarification soil SS was previously named H1, soil OR was named H2 and soil WL was named H3 
Fig. 2 Sequential extraction data from triplicate red mud samples (from location K1, Mayes et al. (2011))

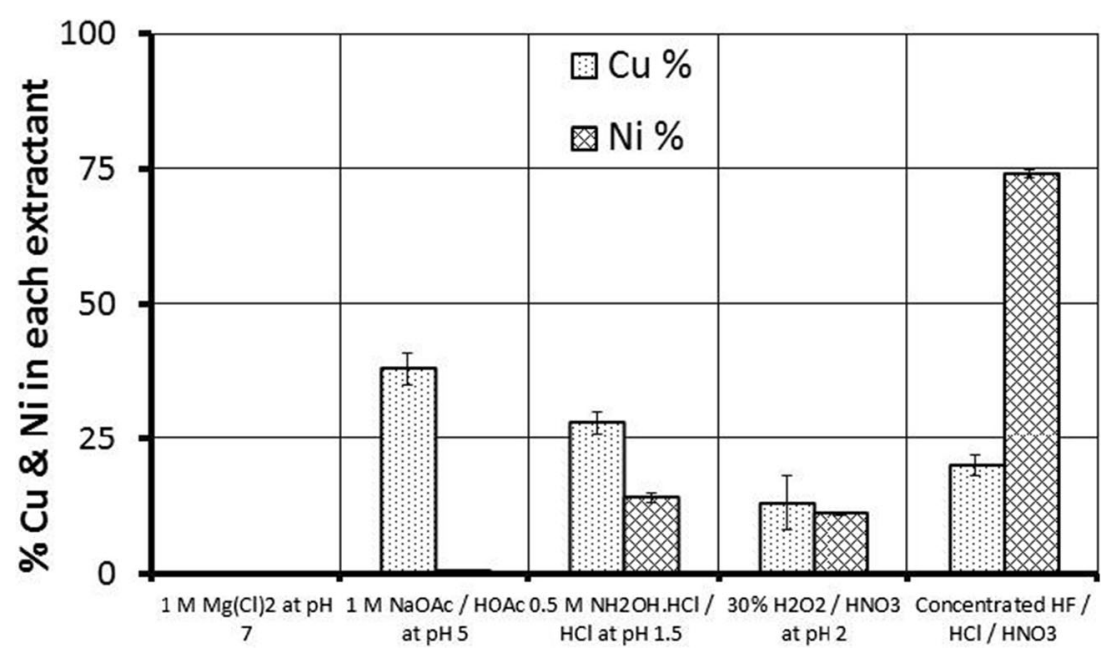

pH 7 and 8 for each soil type (Fig. B, Online Resource). The $\mathrm{pH}$ of the anaerobic and aerobic experiments developed differently over time. The $\mathrm{pH}$ of the $\mathrm{RM}$-amended anaerobic systems (Fig. 3a-c) remained relatively constant after an initial equilibration period. For each soil type, the $33 \%$ RMamended systems had the higher $\mathrm{pH}$, with final $\mathrm{pH}$ values of about 9.5, 10.5 and 11.5 for the OR, WL and SS soils, respectively. The $9 \%$ RM-amended experiments also became more alkaline than the soil-only controls (final $\mathrm{pH}$ values $\sim 8.5,9.5$ and 10 for the OR, WL and SS soils, respectively). The initial $\mathrm{pH}$ values of the aerobic experiments were very similar to those of the equivalent anaerobic experiments; however, the $\mathrm{pH}$ of the aerobic experiments containing red mud gradually decreased over time. The final $\mathrm{pH}$ values of the aerobic $9 \%$ $\mathrm{RM}$ tests were $\mathrm{pH} \sim 8$ with $\mathrm{OR}$ soil and just above $\mathrm{pH} 8.5$ with
WL and SS soil. The final pH values of the aerobic $33 \% \mathrm{RM}$ tests were between a half and one $\mathrm{pH}$ unit higher than the equivalent $9 \%$ RM tests. In all anaerobic experiments, the ORP decreased to between -100 and $-300 \mathrm{mV}$. In the aerobic experiments, it increased to $\sim 250 \mathrm{mV}$ (Fig. $3 \mathrm{~d}-\mathrm{f}$ ).

For each soil, the amount of DOC in solution at the end of testing increases with the RM loading in both anaerobic and aerobic conditions, with significantly higher DOC concentrations in the anaerobic systems than in the equivalent aerobic systems (this is most apparent in the OR Soil, $33 \% \mathrm{RM}$ experiment, where the DOC concentration is $\sim 850 \mathrm{mg} \mathrm{L}^{-1}$ in the anaerobic system, but only $\sim 82 \mathrm{mg} \mathrm{L}^{-1}$ in the aerobic system). Comparison of the three soils indicates that the DOC concentrations in OR soil tests were higher than in the equivalent WL or SS soil tests (the WL and SS soils exhibited
Fig. $3 \mathrm{pH}$ and ORP in anaerobic and aerobic RM-amended experiments over time. Black= anaerobic, white $=$ aerobic. Square $=33 \%$ RM-amended, circle $=9 \%$ RM-amended. Error bars are $1 \sigma$ of triplicate results (where not shown, errors are within the symbol size). Graphs for equivalent unamended controls can be viewed in the Online Resource
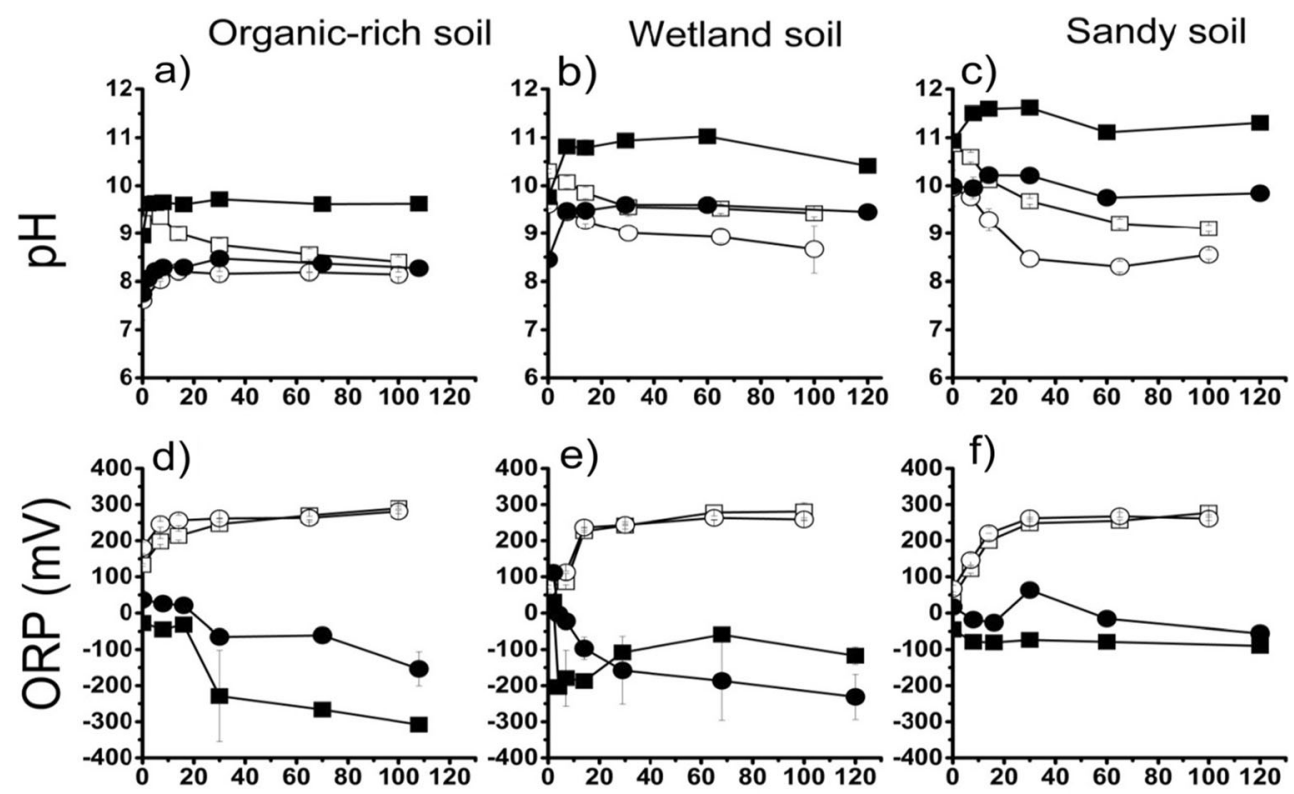

Time (Days) 
broadly similar DOC concentrations in equivalent tests) (Table 2).

Mobilisation of $\mathrm{Cu}$ and $\mathrm{Ni}$ from RM-affected soil-water systems

The aqueous $\mathrm{Cu}$ concentrations in the anaerobic soil-only controls were all $\sim 15 \mu \mathrm{g} \mathrm{L}{ }^{-1}$ and did not vary much with time (see Online Resource, Fig. C). After an equilibration period, the aqueous $\mathrm{Cu}$ concentrations in the anaerobic $\mathrm{RM}$-amended experiments were significantly higher than in the controls (Fig. 4a-c) and increased with the amount of RM added (a slight exception is the OR soil amended with $9 \% \mathrm{RM}$, where the final concentration was only slightly higher than the control, $<25 \mu \mathrm{g} \mathrm{L}^{-1}$ ). The highest aqueous $\mathrm{Cu}$ concentration of $\sim 1450 \mu \mathrm{g} \mathrm{L}^{-1}$ was recorded after 30 days with the OR soil amended with $33 \% \mathrm{RM}$, although this concentration subsequently decreased with time to $\sim 850 \mu \mathrm{g} \mathrm{L}^{-1}$. The aqueous $\mathrm{Cu}$ concentrations in the aerobic controls were generally higher than in the anaerobic controls (typically about $20 \mu \mathrm{g} \mathrm{L}^{-1}$ ) and showed more variation but no trend with time. The aqueous $\mathrm{Cu}$ concentrations in the aerobic RM-amended experiments were generally slightly higher than in the soil-only controls (25-100 $\mu \mathrm{g} \mathrm{L}^{-1}$ ) but significantly lower than in the equivalent anaerobic experiments.

The aqueous Ni concentrations in the anaerobic soil-only controls were all $<10 \mu \mathrm{g} \mathrm{L}^{-1}$ and did not vary much with time. In the anaerobic RM-amended experiments, the aqueous $\mathrm{Ni}$ concentration was higher than in the anaerobic controls and followed a similar pattern to the evolution of aqueous $\mathrm{Cu}$ (although concentrations were about five times smaller). In the anaerobic systems amended with $33 \% \mathrm{RM}$, the final Ni concentrations were 150,42 and $34 \mu \mathrm{g} \mathrm{L}^{-1}$ for the OR, WL and SS soils, respectively. The aqueous Ni concentrations in the aerobic controls were generally slightly lower than in the anaerobic controls (typically $<7 \mu \mathrm{g} \mathrm{L}^{-1}$ ). In the aerobic systems amended with $33 \% \mathrm{RM}$, the final Ni concentrations were 25,6 and $5 \mu \mathrm{g} \mathrm{L}^{-1}$ for the OR, WL and SS soils, respectively (Fig. $4 \mathrm{~d}-\mathrm{f}$ ). Thus, aqueous Ni concentrations in the aerobic RM-amended experiments were similar to those of the equivalent controls, with the exception of the OR Soil amended with $33 \% \mathrm{RM}$, which was four times higher.
Organically bound $\mathrm{Cu}$ and $\mathrm{Ni}$

In all the systems except the WL aerobic control experiment, a significant proportion of the aqueous $\mathrm{Cu}$ was organically complexed (Table 3(A), (B)). This proportion was generally higher in the experiments where red mud was added. In the WL and SS systems, there was generally slightly more organically complexed $\mathrm{Cu}$ in the anaerobic system than in the aerobic systems but very little difference in the OR systems. No organically complexed $\mathrm{Ni}$ was found in either set of controls experiments. However, organically complexed $\mathrm{Ni}$ was found in aerobic experiments with OR and WL soil where $33 \% \mathrm{RM}$ was added, and significant amounts of organically complexed Ni were found in all the anaerobic experiments where RM was added.

\section{Discussion}

\section{Effect of red mud addition on soil $\mathrm{pH}$ and $\mathrm{DOC}$}

When red mud was added to the anaerobic soil-water systems, there was an immediate increase in $\mathrm{pH}$ which was related to the red mud loading, after which the $\mathrm{pH}$ remained relatively constant throughout the incubation period. The change in $\mathrm{pH}$ is due to $\mathrm{NaOH}$ in the red mud, but it varied with soil type due to differences in buffering capacity. The $\mathrm{pH}$ buffering capacities of these soils result from the clay minerals and particularly the organic matter they contain (Lehoux et al. 2013). Alkaline fluctuations are usually buffered by deprotonation reactions (Celik 2004; Stevenson 1994):

$[$ Clay $-\mathrm{M}-\mathrm{OH}]+\left[\mathrm{OH}^{-}\right] \rightarrow\left[\right.$ Clay $\left.-\mathrm{M}-\mathrm{O}^{-}\right]+\mathrm{H}_{2} \mathrm{O}$

$[R-\mathrm{COOH}]+\left[\mathrm{OH}^{-}\right] \rightarrow\left[\mathrm{R}-\mathrm{COO}^{-}\right]+\mathrm{H}_{2} \mathrm{O}$

The dissolution of amorphous and poorly crystalline silica starts to become important in systems with a $\mathrm{pH}$ above 9.8 (Langmuir 1997), so this may also affect the buffering

Table 2 DOC concentrations $\left(\mathrm{mg} \mathrm{L}^{-1}\right)$ at experimental end points

\begin{tabular}{|c|c|c|c|c|c|c|}
\hline & \multicolumn{2}{|c|}{ Soil OR DOC $\left(\mathrm{mg} \mathrm{L}^{-1}\right)$} & \multicolumn{2}{|c|}{ Soil WL DOC $\left(\mathrm{mg} \mathrm{L}^{-1}\right)$} & \multicolumn{2}{|c|}{ Soil SS DOC $\left(\mathrm{mg} \mathrm{L}^{-1}\right)$} \\
\hline & Anaerobic & Aerobic & Anaerobic & Aerobic & Anaerobic & Aerobic \\
\hline Unamended Control & $81( \pm 8)$ & $11( \pm 2)$ & $21( \pm 2)$ & $8( \pm 5)$ & NR & $13( \pm 3)$ \\
\hline $9 \%$ RM Addition & $150( \pm 3)$ & $31( \pm 4)$ & $95( \pm 16)$ & $37( \pm 1)$ & $149( \pm 22)$ & $22( \pm 4)$ \\
\hline $33 \%$ RM Addition & $850( \pm 6)$ & $82( \pm 8)$ & $209( \pm 39)$ & $67( \pm 3)$ & $262( \pm 4)$ & $58( \pm 7)$ \\
\hline
\end{tabular}

$N R$ not analysed 
Fig. 4 Evolution of aqueous $\mathrm{Cu}$ and $\mathrm{Ni}$ over time in anaerobic and aerobic RM-amended experiments. Black=anaerobic, white $=$ aerobic. Square $=33 \%$ RM-amended, circle $=9 \%$ RMamended. Error bars are $1 \sigma$ of triplicate results (not shown, errors are within the symbol size). Graphs for equivalent unamended controls can be viewed in the Online Resource (Fig. C)
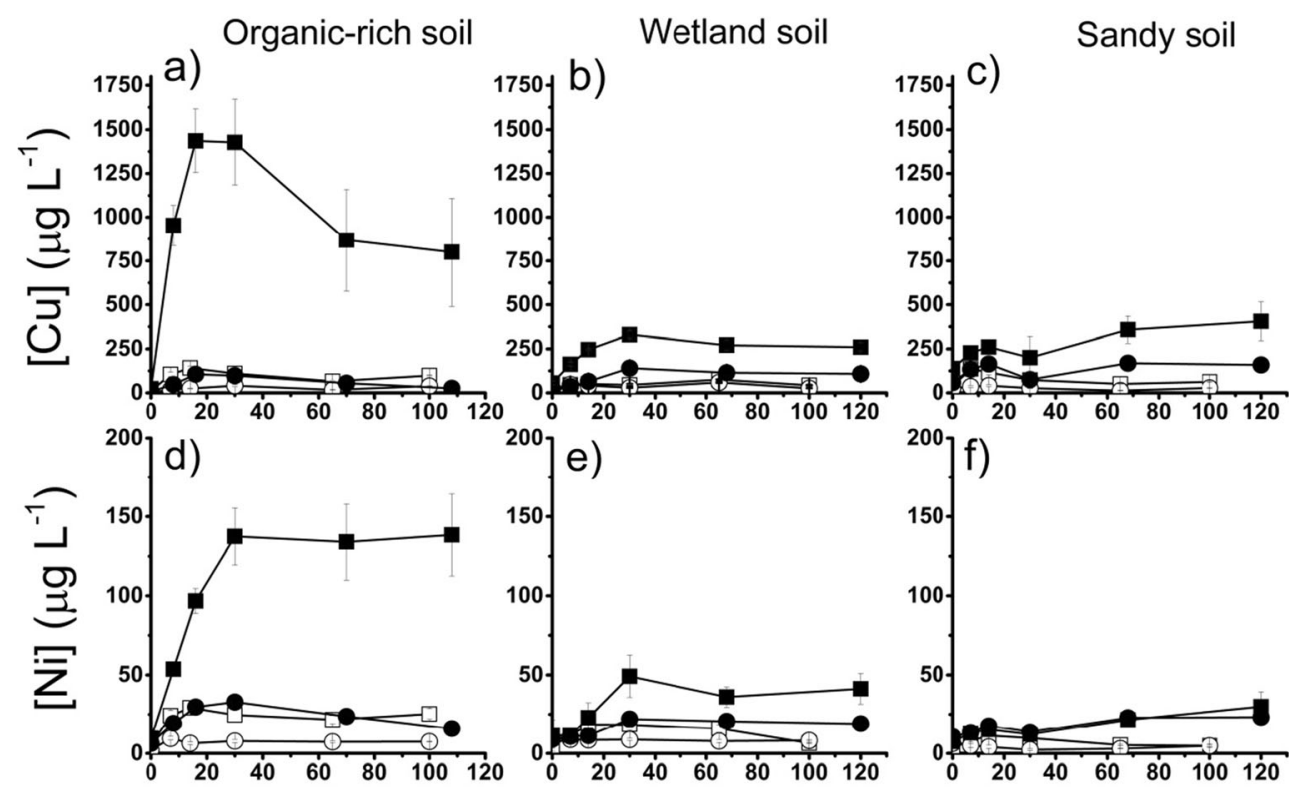

Time (Days) capacity of systems with a high $\mathrm{pH}$ and a high Si content (reaction 3 (Langmuir 1997)).

$$
\left[\mathrm{SiO}_{2}\right]+2\left[\mathrm{H}_{2} \mathrm{O}\right] \rightarrow\left[\mathrm{H}_{2} \mathrm{SiO}_{4}{ }^{-}(+) \mathrm{H}^{+}\right]
$$

Thus, at each red mud loading, the $\mathrm{pH}$ value of the SS system $>$ the WL system $>$ the OR system.

In aerobic systems, the initial increase in $\mathrm{pH}$ upon red mud addition was similar to that observed in the anaerobic systems; however, there was a subsequent gradual decrease of $\mathrm{pH}$. The latter trend can be explained by carbonation by atmospheric $\mathrm{CO}_{2}$, as formation of aqueous carbonate species consumes $\mathrm{OH}^{-}$resulting in a reduction in $\mathrm{pH}$ (Schwab et al. 2006). Carbonate ions tend to react with any divalent cations present (e.g. $\mathrm{Ca}$ (II) and $\mathrm{Mg}$ (II) from either the soils or the red mud) to precipitate carbonate minerals. Thus, the final $\mathrm{pH}$ of all the systems buffers to between 8.0 and 9.5 regardless of soil type. The lower final $\mathrm{pH}$ value of the aerobic experiments resulted in lower measured DOC concentrations in all systems compared to the equivalent anaerobic experiments.

For the anaerobic experiments, the DOC released from the OR systems was between three and four times higher than that released from the WL or SS systems at the same level of red mud loading. This suggests that the amount of soil organic matter present is the main factor controlling DOC release in these experiments (the OR soil has $4.15 \%$ TOC compared to 1.14 and $0.74 \%$ in the WL and SS soils, respectively). The higher initial $\mathrm{pH}$ values of the wetland and sandy soils compared with the OR soil (7.9, 7.9 and 7.0 respectively) may also have meant that SOM in these soils contained a lower proportion of humic acids. Humic acids are the main alkaline soluble

Table $3 \%$ Organically bound aqueous metals from anaerobic (A) and aerobic (B) end point solutions

\begin{tabular}{|c|c|c|c|c|c|c|}
\hline \multirow[t]{2}{*}{ A } & \multicolumn{3}{|l|}{$\% \mathrm{Cu}$} & \multicolumn{3}{|l|}{$\% \mathrm{Ni}$} \\
\hline & Soil OR & Soil WL & Soil SS & Soil OR & Soil WL & Soil SS \\
\hline Unamended controls & $37( \pm 13)$ & $64( \pm 2)$ & NR & $0^{\mathrm{a}}$ & $0^{\mathrm{a}}$ & NR \\
\hline $9 \% \mathrm{RM}$ addition & $73( \pm 6)$ & $91( \pm 1)$ & $57( \pm 9)$ & $28( \pm 6)$ & $34( \pm 9)$ & $14( \pm 2)$ \\
\hline $33 \% \mathrm{RM}$ addition & $70( \pm 7)$ & $80( \pm 3)$ & $73( \pm 7)$ & $46( \pm 10)$ & $39( \pm 7)$ & $48( \pm 13)$ \\
\hline \multirow[t]{2}{*}{ B } & $\% \mathrm{Cu}$ & & & $\% \mathrm{Ni}$ & & \\
\hline & Soil OR & Soil WL & Soil SS & Soil OR & Soil WL & Soil SS \\
\hline Unamended controls & $65( \pm 3)$ & $4( \pm 4)$ & $47( \pm 8)$ & $0^{\mathrm{a}}$ & $0^{\mathrm{a}}$ & $0^{\mathrm{a}}$ \\
\hline $9 \%$ RM addition & $72( \pm 2)$ & $55( \pm 4)$ & $60( \pm 3)$ & $0^{\mathrm{a}}$ & $0^{\mathrm{a}}$ & $0^{\mathrm{a}}$ \\
\hline $33 \% \mathrm{RM}$ addition & $75( \pm 2)$ & $32( \pm 1)$ & $55( \pm 2)$ & $55( \pm 5)$ & $12( \pm 10)$ & $0^{\mathrm{a}}$ \\
\hline
\end{tabular}

$N R$ not analysed

${ }^{\mathrm{a}}$ Inorganic/free $\left[\mathrm{M}^{+}\right]$was $\geq$total $\left[\mathrm{M}^{+}\right]$; therefore, organically bound $\left[\mathrm{M}^{+}\right]$was assumed to be zero 
component of SOM. As conditions become increasingly basic, the humic acids dissociate, and therefore, their solubility is increased (Stevenson 1994). Under aerobic conditions, the DOC concentration in the batch experiment end point solutions was much lower than in the equivalent anaerobic tests (up to 10 times less at the same red mud loading). This was most likely to be due to the lower $\mathrm{pH}$ of the aerobic systems.

\section{Controls on copper release}

$\mathrm{Cu}$ solubility in soils is often controlled by $\mathrm{pH}$. At neutral and high $\mathrm{pH}$ values, $\mathrm{Cu}^{2+}$ adsorbs strongly to negatively charged mineral surfaces, and solution concentrations are low (Peacock and Sherman 2004). In the presence of DOC, $\mathrm{Cu}$ can form stable aqueous organo-metallic complexes thus increasing $\mathrm{Cu}$ concentrations in neutral and alkaline conditions (Davis 1984; Wu et al. 2002). It is therefore important to establish the main control of $\mathrm{Cu}$ mobilisation in these experiments where both $\mathrm{pH}$ and DOC are key variables.

In experiments with a red mud addition, there was no statistically significant correlation (Pearson's $r=<0.5, p=>0.1$; Table 4) between aqueous $\mathrm{Cu}$ concentrations and $\mathrm{pH}$ in either the anaerobic or aerobic systems. However, there was a significant correlation (Spearman's $r=>0.8, p=<0.001$ ) between aqueous $\mathrm{Cu}$ concentrations and DOC concentrations in both systems. Also, as a significant proportion of dissolved $\mathrm{Cu}$ was found to be organically complexed (the fraction retained by the SPE filters), this suggests that dissolution of SOM (specifically the humic acid fraction) is principal control on $\mathrm{Cu}$ solubility in both anaerobic and aerobic experiments. These findings are in agreement with previous work, which found that

Table 4 Spearman's rank correlation values for aqueous $\mathrm{Cu}$ and $\mathrm{Ni}$ concentrations vs $\mathrm{pH}$ or DOC for red mud-amended experiments after $100-120$ days incubation

\begin{tabular}{cllll}
\hline Determinant & \multicolumn{2}{l}{ Experimental conditions } & & \\
\hline & $\begin{array}{l}\text { Anaerobic } \\
r_{\mathrm{s}} \text { value }\end{array}$ & $p$ value & $\begin{array}{l}\text { Aerobic } \\
r_{\mathrm{s}} \text { value }\end{array}$ & $p$ value \\
& & & & \\
{$[\mathrm{Cu}]$ vs } & 0.86 & $<0.001$ & 0.79 & $<0.001$ \\
$\mathrm{DOC}$ & 0.50 & 0.038 & 0.16 & 0.501 \\
$\mathrm{pH}$ & & & & \\
{$[\mathrm{Ni}] \mathrm{vs}$} & 0.78 & $<0.001$ & 0.45 & 0.06 \\
$\mathrm{DOC}$ & 0.43 & 0.08 & -0.46 & 0.05 \\
$\mathrm{pH}$ & &
\end{tabular}

Degrees of freedom was 16 for all correlations (Wessa 2014). Regarding the interpretation of Spearman's $r_{\mathrm{s}}$ and $p$ values, $-r_{\mathrm{s}}$ can be a value between +1 to -1 . An $r_{\mathrm{s}}$ value of 1.0 indicates a perfect linear association, either positive or inverse. $r_{\mathrm{s}}$ of 0 indicates that there is no association, and the closer to 0 the value then the weaker the association. This must be interpreted together with the $p$ value. If $p=<0.05$, the relationship is statistically significant; if $p=>0.05$, there is no statistical significance) $\sim 62 \%$ of $\mathrm{Cu}$ mobilised from soils amended with red mud was associated primarily with OM (Lombi et al. 2002).

For all the tests on the three soils, the amount of $\mathrm{Cu}$ released to solution is less than the amount of $\mathrm{Cu}$ that was present in the soil prior to the addition of red mud (the highest proportion was mobilised in the anaerobic OR $33 \%$ RM test, where it is equivalent to $90 \%$ of the $\mathrm{Cu}$ originally associated with the soil). The sequential extraction data (see Fig. 2 and Table B, Online resource) indicates that very little $\mathrm{Cu}$ is adsorbed to the red mud in exchangeable surface sites $\left.(\sim 0.1 \mathrm{mg} \mathrm{kg})^{-1}\right)$. The fact that most of the $\mathrm{Cu}$ is released to solution by weak acid may be indicative of $\mathrm{Cu}$ present as inner-sphere surface complexes on red mud minerals (i.e. $\mathrm{Cu}$ (II) starts to be released from surfaces when the $\mathrm{pH}$ is below $\sim 6$, for example, the sorption edge value for $\mathrm{Cu}$ on ferrihydrite and hematite is $\sim$ pH 5.2 (Langmuir 1997; Christl and Kretzschmar 2001)) or that $\mathrm{Cu}$ is incorporated in solid phases that are dissolved by the leaching solutions. In the presence of soluble organic compounds, $\mathrm{Cu}$ (II) affinity for surfaces is reduced for all pH values (Ali and Dzombak 1996); therefore, it is possible that the high DOC present in red mud-affected soils may promote release of surface bound $\mathrm{Cu}$ (II) present in red mud. However, it is also possible to account for all of the $\mathrm{Cu}$ released to solution in these experiments by considering just the $\mathrm{Cu}$ originally present in the soils (i.e. the maximum $\mathrm{Cu}$ concentration observed in experiments is equivalent to $\sim 30$ $100 \%$ of the original soil associated $\mathrm{Cu}$ ). In this case, SOMbound $\mathrm{Cu}$ would remain complexed to organic compounds solubilised by the high $\mathrm{pH}$.

The aqueous $\mathrm{Cu}$ concentration in the OR $33 \% \mathrm{RM}$ experiment peaked after 15 days and then decreased with time (Fig. 4a). As the $\mathrm{pH}$ did not vary significantly after day 15 , this decrease in aqueous $\mathrm{Cu}$ concentration is unlikely to be associated with humate solubility. However, the ORP decreased rapidly between 15 and 30 days (Fig. 3d), and sulphate was removed from aqueous solution (see Online Resource, Fig. D) suggesting the occurrence of sulphate reduction. $\mathrm{Cu}$ (II) species are the most stable $\mathrm{Cu}$ species under oxidising conditions, but $\mathrm{Cu}(\mathrm{I})$ and $\mathrm{Cu}(0)$ species are formed under more reducing conditions (Leckie and Davis 1979). Both $\mathrm{Cu}$ (II) and $\mathrm{Cu}$ (I) can form stable complexes with organic matter, but inorganic sulphide is thought to outcompete OM for $\mathrm{Cu}(\mathrm{I})$ in sulphide-rich environments (Fulda et al. 2013b). The Eh/pH diagram for relevant inorganic $\mathrm{Cu}$ species (Fig. 5) confirms that the anaerobic OR $33 \%$ RM test reached an Eh/ $\mathrm{pH}$ state where sulphide can compete for the $\mathrm{Cu}$. There is also evidence for $\mathrm{Cu}$ removal from solution associated with the onset of sulphate reduction (see Online Resource, Fig. D) in the data from the OR $9 \%$ RM experiment (Figs. $4 \mathrm{a}$ and $3 \mathrm{~d}$ : note that the ORP for sulphate reduction is higher at $\mathrm{pH} 8$ than at $\mathrm{pH}$ 9.5). By the end of this test, there was very little $\mathrm{Cu}$ in solution despite an elevated DOC in comparison with the soilonly control (i.e. the end-point of this test did not follow the 


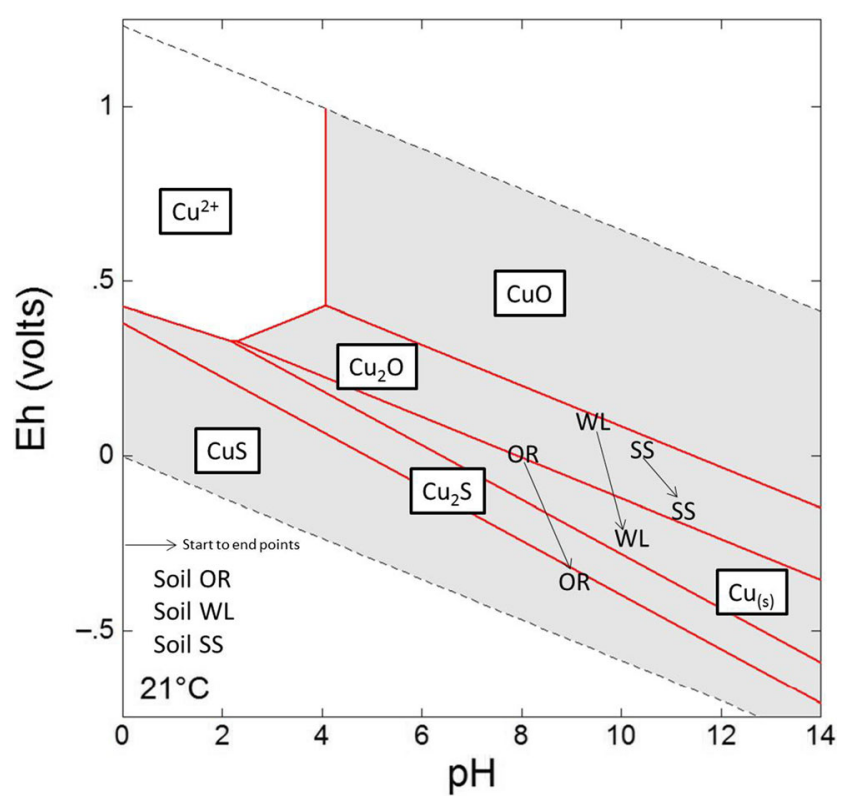

Fig. $5 \mathrm{Eh} / \mathrm{pH}$ conditions calculated for $33 \% \mathrm{RM}$-amended anaerobic experiments superimposed on an $\mathrm{Eh} / \mathrm{pH} \mathrm{Cu}$ species predominance and relative mineral stability diagram calculated using Geochemists Workbench ${ }^{\circledR}$ for $t=21{ }^{\circ} \mathrm{C} / P=1$ at, for the system $\mathrm{Cu}-\mathrm{O}-\mathrm{H}_{-}-\mathrm{SO}_{4}{ }^{2-}$ with $\log \sum \mathrm{Cu} / \mathrm{m}=-.3256, \log \sum \mathrm{SO}_{4}{ }^{2-} / \mathrm{m}-.3646$ and $\mathrm{a}\left[\mathrm{H}_{2} \mathrm{O}_{(\mathrm{aq})}\right]=1$. Points plotted show geochemical conditions at day 0 and experimental end points

trend of increasing aqueous $\mathrm{Cu}$ concentration with increasing DOC concentration). Thus, where the soil $\mathrm{pH}$ and the availability of organic matter favour sulphate reduction, the formation of sulphides can curtail $\mathrm{Cu}$ mobilisation by aqueous humates and therefore lower aqueous $\mathrm{Cu}$ concentrations.

\section{Controls on nickel release}

Nickel solubility decreases with increasing $\mathrm{pH}$ in inorganic systems due to the increased sorption of $\mathrm{Ni}(\mathrm{II})$ species on negatively charged mineral surfaces (Richter and Theis $1980)$, and the tendency of $\mathrm{Ni}(\mathrm{II})$ species $\left[\mathrm{Ni}(\mathrm{OH})^{+}\right.$and $\mathrm{Ni}(\mathrm{OH})_{2}$ ] to form hydrolysed surface complexes or precipitates when $\mathrm{pH}>9$ (for concentrations $<1 \times 10^{-3} \mathrm{M}$ ) (Bradbury and Baeyens 2009; Peacock and Sherman 2007). Whilst Ni speciation is not affected by redox chemistry (Brookins 1988), it is known to form stable complexes with $\mathrm{OM}$ which can increase the solubility of $\mathrm{Ni}$ in some systems (Richter and Theis 1980; Achterberg et al. 1997; Ashworth and Alloway 2004). As with $\mathrm{Cu}$, correlations revealed (Table 4) that in experiments with a red mud addition, there was some correlation (Spearmans's $r_{\mathrm{s}}=>0.4, p=<0.06$ ) between aqueous $\mathrm{Ni}$ concentrations and DOC concentrations in both the anaerobic or aerobic systems (and no statistically significant correlation with $\mathrm{pH}$ ). However, the significance level ( $p=<0.06$ vs. $<0.001)$ and the strength $\left(r_{\mathrm{s}}=>0.4\right.$ vs. $\left.>0.8\right)$ of the correlation was not as high for $\mathrm{Ni}$ as was previously seen for $\mathrm{Cu}$. This maybe because a smaller fraction of $\mathrm{Ni}$ was found to be organically complexed (i.e. retained by the SPE filters) in anaerobic experiments than for $\mathrm{Cu}$. In aerobic experiments, organically bound Ni was only detected in the OR and WL experiments where there was a $33 \%$ addition of red mud.

It is also possible to account for all of the Ni released to solution by considering only the Ni originally present in the soils (i.e. the maximum $\mathrm{Ni}$ concentration observed in experiments is only $2-3 \%$ of the original soil-associated $\mathrm{Ni}$ ). In contrast to $\mathrm{Cu}$, most of the Ni present in red mud was associated with residual phases in the sequential extraction (i.e. those dissolved by HF/aqua regia). For red mud, this includes residual iron oxides including hematite (Mayes et al. 2011). Ni readily substitutes into hematite (Singh et al. 2000); therefore, it is very unlikely that the Ni present in red mud can be mobilised due to the presence of DOC in solution and SOMassociated Ni most probably dominates the Ni released in red mud affected soils.

$\mathrm{An} \mathrm{Eh} / \mathrm{pH}$ diagram for relevant inorganic $\mathrm{Ni}$ species is shown in Fig. 6, with the $\mathrm{Eh} / \mathrm{pH}$ states of the anaerobic tests annotated on it. This figure shows that the thermodynamically stable Ni-containing phase is $\mathrm{NiO}$ without SOM present, except where strongly reducing conditions developed towards the end of the anaerobic OR tests, where sulphidic phase $\left[\mathrm{NiS}_{2}\right]$ should be the stable. However, unlike $\mathrm{Cu}$, there is little change in the aqueous Ni concentration. This may be because a lower proportion of the $\mathrm{Ni}$ is organically bound or may reflect the significantly lower aqueous nickel concentrations $(\mathrm{Cu}$ concentrations are 10 times higher in this experiment,

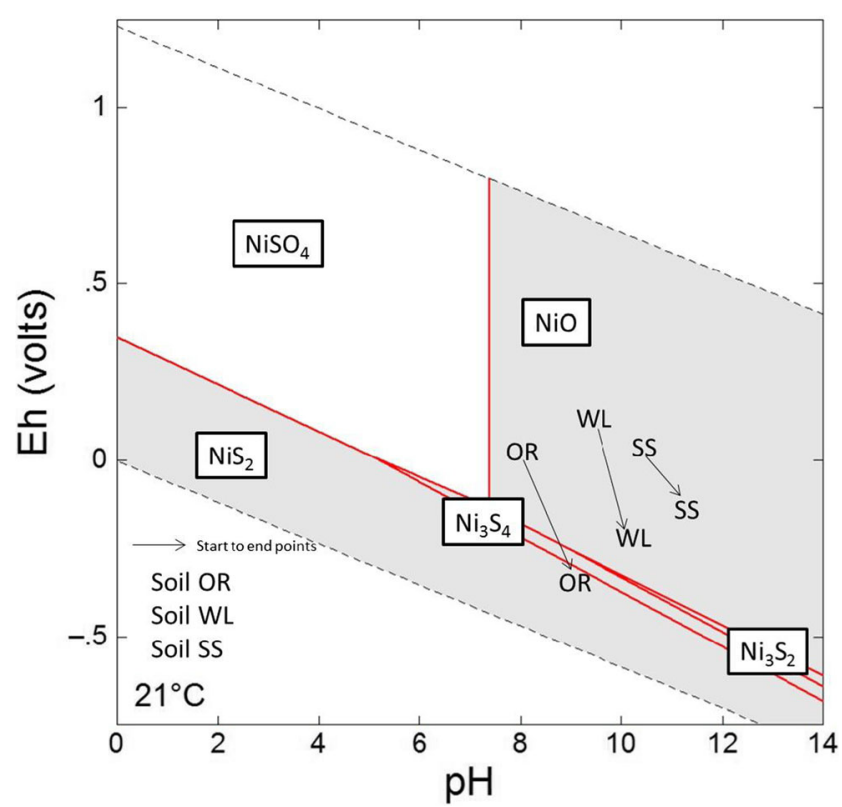

Fig. $6 \mathrm{Eh} / \mathrm{pH}$ conditions calculated for $33 \% \mathrm{RM}$-amended anaerobic experiments superimposed on an $\mathrm{Eh} / \mathrm{pH} \mathrm{Ni}$ species predominance and relative mineral stability diagram calculated using Geochemists Workbench ${ }^{\circledR}$ for $t=21{ }^{\circ} \mathrm{C} / P=1$ at, for the system Ni-O-SO ${ }_{4}{ }^{2-}$ with log $\sum \mathrm{Ni} / \mathrm{m}=-.3256, \log \sum \mathrm{SO}_{4}{ }^{2-}-.3646$ and $\mathrm{a}\left[\mathrm{H}_{2} \mathrm{O}_{(\mathrm{aq})}\right]=1$. Points plotted show geochemical conditions at day 0 and experimental end points 
Fig. 4). These data indicate that DOC is an important mechanism for controlling Ni mobility, especially when DOC concentrations are elevated; although compared to $\mathrm{Cu}$, the affinity for Ni to OM is weaker (Ashworth and Alloway 2004). Furthermore, most of the Ni present in red mud is not likely to easily mobilised, which has resulted in lower aqueous $\mathrm{Ni}$ concentrations despite all three systems containing higher total nickel concentrations when compared to copper.

Implications for red mud affected soils and wetlands

The ploughing of red mud into soil is an effective short-term measure for the prevention of dust formation following a spill to land (Gelencser et al. 2011). This addition of red mud to soil increases soil $\mathrm{pH}$ which in turn releases alkaline-soluble components of SOM into the soil pore water along with any metals complexed to the mobilised SOM. If metals associated with the red mud also become complexed to SOM, this could cause further mobilisation of contaminant metals. In soils taken from the Torna and upper Marcal River, catchments near to, but unaffected by, the Ajka red mud spill $\mathrm{Cu}$ were more readily mobilised by contact with red mud than $\mathrm{Ni}$. This was despite both the soils and the red mud containing more $\mathrm{Ni}$ than $\mathrm{Cu}$. Also, a higher proportion of $\mathrm{Cu}$ in the aqueous phase was organically complexed than $\mathrm{Ni}$ in all three soils under all the conditions investigated. Thus, the difference in $\mathrm{Cu}$ and $\mathrm{Ni}$ mobilisation by red mud addition is most probably associated with the higher affinity of $\mathrm{Cu}$ to form $\mathrm{OM}$ complexes and by the fact that the red mud associated $\mathrm{Cu}$ was much more likely to be mobilised than $\mathrm{Ni}$.

If soils that received red mud are in contact with atmosphere (i.e. are aerobic; as would be expected for most agricultural soils, except during seasonal flooding), the $\mathrm{pH}$ of alkaline pore water is reduced by carbonation reactions; therefore, organic matter dissolution is reduced and the associated $\mathrm{Cu} / \mathrm{Ni}$ mobility is lowered. Therefore, if agricultural soils are expected to remain aerobic over the long-term, then $\mathrm{Cu}$ and $\mathrm{Ni}$ mobilisation will be limited especially for smaller red mud additions.

However, where soils are not in contact with atmosphere (i.e. are anaerobic; as would be expected for a permanemtly flooded wetland environment), soil $\mathrm{pH}$ will remain high $\mathrm{pH}$, and elevated $\mathrm{Cu}$ and $\mathrm{Ni}$ concentrations in the pore water may persist in the long-term. The potential risks are therefore higher in low lying riparian wetlands where large amounts of red mud may have been deposited. $\mathrm{Cu}$ and Ni mobility will be higher in anaerobic than aerobic soils, but if soil conditions become sufficiently reducing (that sulphate reduction occurs), $\mathrm{Cu}$ is removed from solution by reduction of $\mathrm{Cu}(\mathrm{II})$, decomplexation from SOM and the formation of insoluble $\mathrm{Cu}$-sulphide mineral phases. However, in this study, this only occurred in experiments with high organic matter content and where potentially there could be very high $\mathrm{Cu}$ concentrations in solution.

\section{Conclusion}

The amendment of a range of soils with red mud resulted in mobilisation of $\mathrm{Cu}$ and $\mathrm{Ni}$ to solution. The high $\mathrm{pH}$ conditions imposed by the red mud on soils resulted in higher concentrations of DOC and organically complexed metals. Therefore, soils with higher organic matter content experienced larger metal releases. In all cases, $\mathrm{Cu}$ was preferentially released with respect to $\mathrm{Ni}$, despite the higher overall abundance of $\mathrm{Ni}$ in solids, due to a higher affinity of $\mathrm{Cu}$ to form organic complexes. Aerobic conditions resulted in lower $\mathrm{pH}$, due to carbonation reactions, lower overall DOC concentrations and lower $\mathrm{Cu}$ and $\mathrm{Ni}$ release. Carbonation was absent under anaerobic condition, and higher $\mathrm{Cu}$ and $\mathrm{Ni}$ concentration persisted in these experiments. In experiments where sulphate reduction was observed, $\mathrm{Cu}$ (II) reduction resulted in the partial removal of $\mathrm{Cu}$ from solution. Overall, the addition of high concentrations red mud to soils should be avoided, especially to organic-rich soils in permanently anaerobic environments.

Acknowledgments The authors acknowledge funding from the UK Engineering and Physical Science Research Council (EP/P505593/1). We acknowledge additional support from UK Natural Environment Research Council (NE/I019468/1). We thank Lesley Neve, Rachel Gasior (University of Leeds), Bob Knight (University of Hull), Nick Marsh (University of Leicester), Jane Davis (University of Newcastle) and Ann Mennim (University of Edinburgh) for assistance with XRD, DOC, ICP-MS/OES, XRF, sequential extraction and TOC analysis, respectively.

Conflict of interest The authors declare that there is no conflict of interest.

Open Access This article is distributed under the terms of the Creative Commons Attribution License which permits any use, distribution, and reproduction in any medium, provided the original author(s) and the source are credited.

\section{References}

Achterberg EP et al (1997) Speciation and cycling of trace metals in Esthwaite Water: a productive English lake with seasonal deepwater anoxia. Geochim Cosmochim Acta 61(24):5233-5253

Adam J, Banvolgyi G, Dura G, Grenerczy G et al (2011) The Kolontar report: causes and lessons from the red mud disaster. Sustainable Development Committee of the Hungarian Parliament, Budapest

Ali MA, Dzombak DA (1996) Effects of simple organic acids on sorption of $\mathrm{Cu}^{2+}$ and $\mathrm{Ca}^{2+}$ on goethite. Geochim Cosmochim Acta 60(2):291-304

Anton A et al (2012) Modelling the Potential Effects of the Hungarian Red Mud Disaster on Soil Properties. Water Air Soil Pollut 223(8):5175-5188

Ashworth DJ, Alloway BJ (2004) Soil mobility of sewage sludge-derived dissolved organic matter, copper, nickel and zinc. Environ Pollut 127(1):137-144

Baken S et al (2011) Metal Complexation Properties of Freshwater Dissolved Organic Matter Are Explained by Its Aromaticity and by Anthropogenic Ligands. Environ Sci Technol 45(7):2584

Bradbury MH, Baeyens B (2009) Sorption modelling on illite Part I: Titration measurements and the sorption of $\mathrm{Ni}, \mathrm{Co}, \mathrm{Eu}$ and $\mathrm{Sn}$. Geochim Cosmochim Acta 73(4):990-1003 
Brookins D (1988) Eh, pH diagrams for geochemistry. Springer-Verlag, Berlin

Burke IT et al (2012) Speciation of arsenic, chromium, and vanadium in red mud samples from the ajka spill site, hungary. Environ Sci Technol 46(6):3085-3092

Burke IT et al (2013) Behavior of Aluminum, Arsenic, and Vanadium during the Neutralization of Red Mud Leachate by $\mathrm{HCl}$, Gypsum, or Seawater. Environ Sci Technol 47(12):6527-6535

Celik MS (2004) Electrokinetic behaviour of clay surfaces. In: Wypyck F, Satyanarayana KG (eds) Clay surfaces: fundamentals and applications. Elsevier Ltd., London

Cheshire MV et al (1977) METAL DISTRIBUTION AND NATURE OF SOME CU, MN AND V COMPLEXES IN HUMIC AND FULVIC-ACID FRACTIONS OF SOIL ORGANIC-MATTER. Geochim Cosmochim Acta 41(8):1131-1138

Christl I, Kretzschmar R (2001) Interactions of $\mathrm{Cu}$ and fulvic acid at the hematite-water interface. Geochim Cosmochim Acta 65(20):34353442

Davis JA (1984) Complexation of trace metals by adsorbed natural organic matter. Geochim Cosmochim Acta 48:679-691

Enserink M (2010) ENVIRONMENT After Red Mud Flood, Scientists Try to Halt Wave of Fear and Rumors. Science 330(6003):432-433

Fulda B et al (2013a) Redox transformation, solid phase speciation and solution dynamics of copper during soil reduction and reoxidation as affected by sulfate availability. Geochim Cosmochim Acta 123: 385-402

Fulda B et al (2013b) Copper Redox Transformation and Complexation by Reduced and Oxidized Soil Humic Acid. 1. X-ray Absorption Spectroscopy Study. Environ Sci Technol 47(19):10903-10911

Gelencser A et al (2011) The red mud accident in Ajka (Hungary): characterization and potential health effects of fugitive dust. Environ Sci Technol 45(4):1608-1615

Grafe M et al (2011) Bauxite residue issues: III. Alkalinity and associated chemistry. Hydrometallurgy 108(1-2):60-79

Hind AR et al (1999) The surface chemistry of Bayer process solids: a review. Colloids Surf A Physicochem Eng Asp 146(1-3):359-374

Klebercz O et al (2012) Ecotoxicity of fluvial sediments downstream of the Ajka red mud spill, Hungary. J Environ Monitor JEM 14(8):2063-2071

Langmuir D (1997) Aqueous environmental geochemistry. Prentice Hall, Upper Saddle River

Leckie JO, Davis JA (1979) Aqueous Environmental Chemistry of Copper. In: Nriagu JO (ed) Copper in the Environment Part 1: Ecological Cycling. John Wiley \& Sons Inc., New York

Lehoux AP et al (2013) Gypsum addition to soils contaminated by red mud: implications for aluminium, arsenic, molybdenum and vanadium solubility. Environ Geochem Health 35(5):643-656

Liu Y et al (2007) Characterization of red mud derived from a combined Bayer Process and bauxite calcination method. J Hazard Mater 146(1-2):255-261

Lockwood CL et al (2014) Mobilisation of arsenic from bauxite residue (red mud) affected soils: effect of $\mathrm{pH}$ and redox conditions. Appl Geochem 51:268-277

Lombi E et al (2002) In situ fixation of metals in soils using bauxite residue: chemical assessment. Environ Pollut 118(3):435-443

Mayes WM et al (2011) Dispersal and Attenuation of Trace Contaminants Downstream of the Ajka Bauxite Residue (Red Mud) Depository Failure, Hungary. Environ Sci Technol 45(12):5147-5155

Milacic R et al (2012) Environmental impact of toxic elements in red mud studied by fractionation and speciation procedures. Science of the Total Environment 426:359-365

Moon EM, Peacock CL (2013) Modelling Cu(II) adsorption to ferrihydrite and ferrihydrite-bacteria composites: deviation from additive adsorption in the composite sorption system. Geochim Cosmochim Acta 104:148-164
Nagy AS et al (2013) Trace metal and metalloid levels in surface water of the Marcal River before and after the Ajka red mud spill, Hungary. Environ Sci Pollut Res 20(11):7603-7614

Parsons JW (1988) Isolation of humic substances from soils and sediments. In: Frimmel FH, Christman RF (eds) Humic substances and their role in the environment. John Wiley \& Sons, Berlin, pp 3-14

Peacock CL, Sherman DM (2004) Copper(II) sorption onto goethite, hematite and lepidocrocite: a surface complexation model based on ab initio molecular geometries and EXAFS spectroscopy. Geochim Cosmochim Acta 68(12):2623-2637

Peacock CL, Sherman DM (2007) Sorption of Ni by birnessite: equilibrium controls on Ni in seawater. Chem Geol 238(1-2):94-106

Power G et al (2011) Bauxite residue issues: I. Current management, disposal and storage practices. Hydrometallurgy 108(1-2):33-45

Rauret $\mathrm{G}$ et al (1989) OPTIMIZATION OF TESSIER PROCEDURE FOR METAL SOLID SPECIATION IN RIVER SEDIMENTS. Int J Environ Anal Chem 36(2):69-83

Reeves HJ, Wealthall G, Younger PL (2011) Advisory visit to the bauxite processings tailings dam near Ajka, Vesprem County, western Hungary. British Geological Survey, Keyworth

Rekasi M et al (2013) Effects of leaching from alkaline red mud on soil biota: modelling the conditions after the Hungarian red mud disaster. Chem Ecol 29(8):709-723

Renforth P et al (2012) Contaminant mobility and carbon sequestration downstream of the Ajka (Hungary) red mud spill: the effects of gypsum dosing. Sci Total Environ 421-422:253-259

Richter RO, Theis TL (1980) Nickel speciation in a soil/water system. In: Nriagu JO (ed) Nickel in the Environment

Rubinos DA, Barral MT (2013) Fractionation and mobility of metals in bauxite red mud. Environ Sci Pollut Res Int 20(11):7787-7802

Ruyters S et al (2011) The red mud accident in Ajka (Hungary): plant toxicity and trace metal bioavailability in red mud contaminated soil. Environ Sci Technol 45(4):1616-1622

Schwab AP et al (2006) Characteristics of blast furnace slag leachate produced under reduced and oxidized conditions. J Environ Sci Health A Toxicol Hazard Subst Environ Eng 41(3):381-395

Secretariat of the Basel Convention (2011) Basel Convention of the control of transboundary movements of hazardous waste and their disposal. Protocol on liability and compensation for damage resulting from transboundary movements of hazardous wastes and their disposal. Texts and Annexes. Annex IX, List B2, B2110, pg 81

Singh B et al (2000) Structural chemistry of Fe, Mn, and Ni in synthetic hematites as determined by extended X-ray absorption fine structure spectroscopy. Clay Clay Miner 48(5):521-527

Sparks DL, Scheidegger AM, Strawn DG, Scheckel KG (1998) Kinetics and mechanisms of metal sorption at the mineral-water interface. In: Sparks DL, Grundl TJ (eds) Mineral-water interfacial reactions: kinetics and mechanisms. Washington, ACS

Stevenson FJ (1994) Humus chemistry: genesis, composition, reactions. John Wiley and Sons Inc.

Thomas B (2000) Solid phase extraction for the removal of organic-iron complexes in contaminated groundwater. MSc thesis, The University of Leeds

Weber F-A et al (2009) Multi-metal contaminant dymanics in temporarily flooded soil under sulfate limitation. Geochim Cosmochim Acta 73: $5513-5527$

Wessa P (2014) Free Statistics Software, Office for Research Development and Education, Version 1.1.23-r7. [Online]. [Accessed 24th September 2014]. Available from: http://www.wessa.net

Wu J et al (2001) Copper(II) humate mobility in kaolinite soil. Eng Geol $60: 275-284$

Wu J et al (2002) Effect of humic substances on $\mathrm{Cu}$ (II) solubility in kaolin-sand soil. J Hazard Mater 94(3):223-238

Yin YJ et al (2002) The importance of oarganic matter distribution and extract soil: solution ratio on the desorption of heavy metals from soils. Sci Total Environ 287(1-2):107-119 